\title{
SCOTTISH STUDIES
}

\section{John Bunyan in the Kilt:}

\section{The Influence of Bunyan Texts on Religious Expression and Experience in the Scottish Highlands and Islands}

DONALD E. MEEK

ABSTRACT

No abstract. 


\title{
John Bunyan in the Kilt: The Influence of Bunyan Texts on Religious Expression and Experience in the Scottish Highlands and Islands
}

\author{
DONALD E. MEEK
}

Dr John MacInnes has contributed greatly to our understanding of many different aspects of Highland and Gaelic culture, including evangelical Protestantism and its impact on Gaelic secular tradition. He has also had much to say about translation, commonly from Gaelic to English, and most frequently in the context of insightful reviews of modern Gaelic verse. In appreciation of John's warm-hearted sharing of insights into both subjects, from which I have benefited immensely, I am delighted to offer him in return a beannachadh which combines both the Christian faith and also translation, though, on this occasion, from English to Gaelic. As John is well aware, evangelical Protestantism in its Highland garb was deeply indebted to seventeenth-century English Puritan writers such as Richard Baxter (1615-1691) of Kidderminster, whose Call to the Unconverted was translated into Gaelic in 1750, thus establishing a literary genre which has continued, though in diminishing form, well into the twentieth century. In particular, I wish to consider the writings of John Bunyan (1628-1688) of Bedford, whose work is well known in the British Isles, and has been translated into many languages, including Gaelic (Sharrock 1968; Dunan-Page 2010).

Back in my boyhood days in Tiree, I was a regular attender at Gaelic church services, which were held by both the Baptist church and the Church of Scotland in the island. The sermon was always the test of my boyhood stamina. In addition to paying close attention to the fine woodcuts of coal-carrying puffers and other steamships which had been cut into the pews of the most popular church buildings by an earlier generation of homiletic enthusiasts, I used to find some degree of relaxation from doctrinal tedium in the many anecdotes, illustrations and citations with which the best sermons were equipped. Sometimes no source would be given for the anecdote, but occasionally the source would be provided, in order to strengthen the argument. It was not uncommon for the preacher to appeal to a certain John Bunyan, who was apparently one of the greatest storytellers and wisdom figures of all time. On such occasions, the preacher would preface his observations with the phrase, 'Mar a thuirt Iain Buinian...'('As John Bunyan said...'), as if he were appealing to the ultimate authority beyond Scripture. Most frequently, allusion would be made to a book called Turas a' Chriosdaidh, which had a wealth of wonderful characters and spinechilling encounters. My own favourite character was Famhair gun Dòchas, 'Giant without Hope'. The preacher offered no explanation of Bunyan's background or origins, and, in my boyhood innocence, I assumed that Bunyan was a Gaelic-speaking Highlander. Later, as my innocence declined and my literacy increased, I became familiar with Bunyan's role in English as well as Gaelic literature, and gradually the realisation dawned upon me that Bunyan was not a Highlander after all. He was, in fact, an Englishman who had lived in the middle of the seventeenth century. Turas a' Chriosdaidh meant 'The Pilgrim's Progress', and there was a copy of it in my own home, as in many other similar homes throughout the Highlands and Islands. Indeed, I remember seeing a wonderful Gaelic edition with woodcuts which showed Christian fighting Apollyon. Its pages were becoming damp and mouldy, and I can still recollect its smell and texture. I might add that, when I came to Edinburgh in 1979, I noticed that a coal-merchant called John Bunyan had a yard close to Haymarket Station, and I used to reflect wryly on how another John Bunyan, far removed in time and place, was a major supplier of fuel for sermons and books in the Highlands and Islands - and far, far beyond. 
In the course of my forays into Highland church history, I came to realise that John Bunyan was perhaps the religious writer who had been most frequently, and most consistently, translated into Gaelic. Interestingly, the translation of his works had been undertaken mainly in the first half of the nineteenth century, at a time when the evangelical movement, spearheaded by ministers and missionaries of various kinds, but especially by schoolmasters, was touching the farthest corners of the Highands and Islands. Evangelicalism did not make a noticeable impact on the island of Lewis until the 1820s. As part of the burgeoning evangelical movement, literacy in Gaelic was spreading, particularly through the labours of the Gaelic School Societies, the first of which was established in Edinburgh in 1811. These societies aimed to make the Gaelic people sufficiently literate in Gaelic to be able to read the Gaelic Bible, which had been completed in 1801. The Gaelic Bible was the key text in these schools, but it is clear that a taste in reading beyond the Bible was also stimulated. The translation of Bunyan texts reflects, and accompanies, the vigorous indigenisation of evangelicalism in the Highlands and Islands, and it seems to me that the easy-flowing, natural style of the Bunyan translations, and especially of Pilgrim's Progress, matched the increasing appeal of the evangelical movement to the general mass of the Gaelic people. The Bunyan books, in their Gaelic forms, represent a critical stage in the important exchange between donor and receptor cultures in a missionary context. Even today, the original Gaelic text of The Pilgrim's Progress is easily accessible, and it is very different in texture from the general run of Puritan translations into Gaelic. It avoids what I sometimes call 'Puritanese' and its accompanying Highland counterpart, 'Westminster Gaelic', which is stiff and rigid and doctrinally precise. It is much closer to the everyday Gaelic of the people themselves (Meek 2002a).

The history of the Gaelic version of The Pilgrim's Progress will set the scene. It was translated as Turas a' Chriosdaidh, and it first appeared in Edinburgh in 1812. The work was undertaken by Patrick MacFarlane, a schoolmaster in Appin, Argyll, who lived from 1758 to 1832. Schoolmasters were very important figures, not only in spreading the evangelical message, but also in translating key works of the evangelical movement. In this respect, they were more important than the ministers. They had a zeal for routine translation which the ministers, on the whole, lacked. To put it another way, ministers were more inclined to translate high-prestige works, such as the Gaelic Bible, which was undertaken by a succession of ministers. Ministers preferred to write Gaelic prose, rather than translate it, and they made a massive contribution to original Gaelic prose writings. Schoolmasters, on the other hand, undertook the more mundane tasks of translating catechisms and Puritan texts, though the distinction is not entirely rigid, as we shall see. MacFarlane, as a representative of the 'typical' translator, had a considerable range of interests and abilities. He was the translator of two of Philip Doddridge's works, Rise and Progress of Religion in the Christian Soul, and One Thing Needful, which were both published in Edinburgh in 1811. In addition, he produced a collection of Gaelic poetry in 1813, and a Gaelic vocabulary in 1815. This in itself is sufficient to show that evangelicalism was paying attention to the secular, as well as the spiritual, needs of the Gaelic people. Because of his various excursions into Gaelic culture, MacFarlane had a particular sensitivity to Gaelic language levels. Once in print, his translation became a firm favourite in the Highlands and Islands. It went through thirteen editions in the course of the century, and has retained its pre-eminent place to the present day. ${ }^{1}$

There were, of course, further translations. In 1865 a translation by Dr T. R. MacGillvray was published in Glasgow, a tome of some 940 pages, which included some of Bunyan's other works. This was the work that contained the woodcuts which I remember from my boyhood. In the twentieth century, Pilgrim's Progress was also translated by the Rev. Dr Malcolm MacLennan, and published in Edinburgh in 1929. It was reprinted in 1953 with a memoir of the translator by the Rev. T. M. Murchison. This illustrates the continuing appeal of Pilgrim's Progress to the Gaelic

\footnotetext{
${ }^{1}$ For dates and details of early Gaelic Bunyan texts, see Maclean 1915: 40-46.
} 
people. As Murchison points out, MacLennan's translation uses the dialect of Uig, his native part of Lewis (MacGhillinnein 1953: 3-4). In this translation, then, the tinker of Bedford speaks with the cadences of a Lewisman! What greater honour could possibly be bestowed upon him? His cultural apotheosis is most surely complete!

Several other Bunyan texts were translated into Gaelic in the first half of the nineteenth century, and it is instructive to observe the pattern. These were as follows:

$\begin{array}{ll}\text { Life and Death of Badman } & 1824 \text { (Inverness) } \\ \text { The Barren Fig Tree } & 1824 \text { (Inverness) } \\ \text { World to Come } & 1825 \text { (Tain) } \\ \text { Sighs from Hell } & 1829 \text { (Inverness) } \\ & 1846 \text { (Edinburgh) } \\ \text { Heavenly Footman } & 1829 \text { ((Inverness) } \\ \text { Water of Life } & 1835 \text { (Inverness) } \\ & 1846 \text { (Edinburgh) } \\ \text { Holy War } & 1840 \text { (Inverness) } \\ \text { Come and Welcome } & 1844 \text { (Edinburgh) } \\ \text { Grace Abounding } & 1847 \text { (Edinburgh) }\end{array}$

It will be evident that the Bunyan texts were translated mainly in two periods - in fact, two different decades. The first period was in the 1820 s, in the wake of the creation of the Gaelic school societies and the triumph of evangelicalism in the Outer Hebrides, and the second phase was in the 1840 s, immediately before and immediately after the Disruption of 1843 , when the Free Church of Scotland emerged from the Church of Scotland (Meek 1998). There was a quickening pulse, so to speak, in both of these periods, and each seems to have been marked by the translation of Bunyan texts. This in itself would suggest that, in times of heightened religious enthusiasm or 'revival', Highlanders were inclined to turn to Bunyan as one of the key interpreters of the evangelical experience, and as a guide to spiritual expression. The post-Disruption period witnessed the retranslation of two of the works, Sighs from Hell and Water of Life. Thereafter there were no significant translations of Bunyan until the twentieth century, although the earlier translations were regularly reprinted.

It is worth noting who translated some of these texts. One of the translators was a certain Robert MacDonald (b. 1795), a Gaelic schoolmaster from Sutherland, who was responsible for the translation of Life and Death of Badman (1824) and the first of the translations of Sighs from Hell (1829). MacDonald was schoolmaster in different parts of the northern Highlands - Arnisdale (Loch Hourn), Inverness, Keils and Dingwall; a collection of his own verse, published in 1836, contained some satirical sermons. But perhaps the most remarkable of all the translators was the man who undertook the translation of several of the volumes published in the 1840s, including Grace Abounding - John MacKenzie. This was none other than the celebrated John MacKenzie (1806-48), from Gairloch, who collected much Gaelic verse, and produced the fine anthology called Sar Obair nam Bàrd Gaelach: The Beauties of Gaelic Poetry, which was first published in 1841 , and is still regarded as a major source of Gaelic poetry and information about the poets. MacKenzie also wrote a Gaelic account of the adventures of Bonnie Prince Charlie, and compiled a Gaelic dictionary (Maclean 1915: 246-50).

It is one of the more curious aspects of modern Gaelic scholarship that, although MacKenzie's massive achievement in producing the Beauties of Gaelic Poetry is regularly and rightly applauded, his role as a translator of John Bunyan's work has hardly ever been noted. This fits conveniently with the general scholarly perception - a modern misperception in my opinion - that there was some sort of unbridgeable gulf between the evangelical movement and the secular world, and that evangelicals helped to destroy Gaelic culture. I cannot comment at this stage on John MacKenzie's commitment to evangelicalism, but it is self-evident that he saw considerable benefits in translating 
Bunyan and also in collecting Gaelic song and verse composed by the secular and sacred bards of the Highlands. My own view is that the supposed antipathy of evangelicals to Gaelic culture has been greatly exaggerated, largely because of the effect of the quarrels within the Free Church in the later part of the nineteenth century, and the narrowing of spiritual horizons caused by the creation of the Free Presbyterian Church in 1893. Whatever evangelicals may have thought about the more decadent aspects of Gaelic culture which they tried to eradicate, they participated in literary creativity and in Gaelic scholarship throughout most of the nineteenth century (Meek 1996: 34-53). That there was two-way traffic between Gaelic culture and the evangelical movement is splendidly evidenced by the work of John MacKenzie of Gairloch. I should add that MacKenzie was also the editor of Patrick MacFarlane's fine translation of Pilgrim's Progress of 1812, and that he produced a new edition of it in 1845. All in all, MacKenzie's role as a Bunyan editor and translator of Bunyan texts into Gaelic is one of the best-kept secrets of the Gaelic world.

We should also note that the creative interest in Bunyan which is evident by the 1840 s is connected with the northern Highlands, and particularly Ross-shire, as the work of John MacKenzie so clearly indicates. The first translation of a Bunyan text, however, was made in Appin, Argyll, by Patrick MacFarlane, and published in 1812. Enthusiasm for Bunyan had thus moved north by 1850 , probably because of the popularity of the 1812 text. As Ross-shire was a focus of evangelical Calvinism in the seventeenth and eighteenth centuries, it is fascinating to see Bunyan finding such a firm place in that quarter in the first half of the nineteenth century. Inverness also stands out very prominently as a publication centre for Bunyan texts, producing as many translations as Edinburgh.

The influence and appeal of Bunyan in the Highlands and Islands can be detected in ways other than the citation of places of publication and the names of translators. It can be seen in poetry and in preaching too, especially in the first half of the nineteenth century. In the field of hymnology, for instance, the influence of Bunyan can be detected on Peter Grant (c. 1783-1867), the pastor of the Baptist Church at Grantown-on-Spey (Meek 2002b). Grant, who was an ardent evangelist and itinerant preacher who travelled the length and breadth of the northern Highlands and Islands on preaching tours, became perhaps the most popular of all composers of Gaelic hymns in the nineteenth century. One of the themes that he pursues fairly frequently in his compositions is the journey of the Christian from the fragile and perishing world of humanity to the Heavenly City. The path is strewn with snares and difficulties of all kinds. It is hard to believe that Bunyan's Pilgrim's Progress did not mould the thoughts of the Gaelic hymnwriter as he constructed his concept of spiritual itineration. The journey of life is a common metaphor, of course, but Bunyan's work invested it with a special significance for the Christian believer. The believer becomes the Christian pilgrim, making his or her way through the desert of this world, avoiding fleshly temptations and Satan's darts wherever possible. Ioan Williams' comments on the influence of the Welsh translation of Pilgrim's Progress are applicable to both Grant's hymns and wider self-perception in the Christian communities of the Scottish Highlands and Islands (Williams 2000: 50):

Well before the end of the eighteenth century, Welsh Calvinism had developed a characteristic system of social and psychological structures. At the centre of this system was the concept of the Christian as pilgrim, inherited from Bunyan, whose Pilgrim's Progress (1676) had long been assimilated into Welsh culture in its translated version as Taith y Pererin (1688).

The modes and styles of Bunyan, and in particular the personification of attitudes and arguments, in such characters as Mr Valiant for Truth and Giant Despair, worked their way into the sermons of some Highland preachers. Perhaps the most conspicuous of these was the Rev. Robert Finlayson (1793-1861), a native of Latheron in Caithness. After study at King's College, Aberdeen, Finlayson ministered in the Gaelic Chapel in Aberdeen for three years. Thereafter he became minister of Knock in Lewis, and then moved to Lochs. As a young boy, he had been influenced by his father's library, which included Thomas Boston's Four-fold State and Dyer's Christ's Famous 
Titles (both of which were translated into Gaelic), but which also had copies of Bunyan's works. (Note again, in the bygoing, the northern location of Bunyan, this time in Caithness and Lewis.) In the course of his ministry in Lewis, Finlayson earned the nickname of 'the John Bunyan of the Highlands', because of his Bunyanesque techniques. Finlayson's great gift was his ability to bring characters to life in his sermons, in such a way that his listeners were treated to what might be regarded nowadays as dramatic renditions. As Dr Roderick MacLeod notes in his fine paper on Finlayson (MacLeod 1986):

Finlayson's method preaching must have been like a breath of fresh air to congregations who had been accustomed to the rather dry, dull and scholarly sermons of the Moderates. He had the intriguing habit of addressing Biblical characters by name in the course of his sermons. Preaching on the Flood, he cried, "Ho, ho, Noah! What a wonderful Admiral you, of this Ark! Many an old crock has floated the seas, but yours was the strangest of all the ships of the world's fleets, and your cargo the most amazing." Another device employed by the minister of Lochs to make personalities from Biblical history more meaningful to his audience, was to place them in a Hebridean setting...A bull from the Butt of Lewis and a ram from Uig feature in his colourful sermon on Noah's Ark.

Finlayson's Bunyanesque style is even more evident in his sermon on Peter's denial of Christ, in which he personifies Zeal and Knowledge:

Out went Zeal after Christ, and when Jesus said, "You will all be offended in me tonight," Zeal replied, "Though all others are offended in you, I shall not be." But Jesus said to him, "Verily I say unto you today, on this very night, before the cock crows twice, you will deny me thrice." Zeal ran home to Knowledge in tears.

"What has come over you now, Zeal?" asked Knowledge. "Woe is me," said Zeal, "I was foolish. I provoked my Lord and He claimed that I would be guilty of denying Christ!"

Bunyan, then, provided a homiletic model for Gaelic ministers with a creative approach to evangelism and a desire to convey their teaching through forms of ecclesiastical drama. Again, we can cite Welsh parallels, most noticeably in the case of the North Wales Baptist preacher, Christmas Evans (1776-1838), who was regularly compared with Bunyan because of the 'long-sustained parables and pictures alive with allegorical delineation of human character'. In his sermons, it is said that Evans himself was both 'playwright and actor' (Shenton 2001: 398-99).

Bunyan also provided a model for individual believers, by offering a paradigm for faith - and perhaps even for revolutionary politics. We can observe this in Lewis, in comments made by the Gaelic poet, John Smith (1848-81) of Iarsiadar in Lochs, one of the finest of the many Gaelic poets of the nineteenth-century Highlands, and a radical voice in the reaction to oppressive landlordism. Smith composed a couple of major poems in which - perhaps under Bunyan's influence - he personified (not unlike Finlayson of Lochs) virtues such as Kindliness and vices such as Pride, and addressed these in his verse. In his song Spiorad a' Charthannais, 'The Spirit of Kindliness', he examines the impact of imperialism and economic determinism on the contemporary Highlands, arraigning alike the militaristic war-mongers of his day and the ruthless landlords whose agents are intent on emptying the glens and the islands of their people. He also turns his spotlight on the contentious, introverted and gloomy kind of religious experience with which he was apparently familiar in Lewis by the 1870s. He provides a word picture of the Christian who is committed to that sort of creed:

That surly, gloomy Christian who meditates so hard, 
who assumes a holy countenance

like a prophet in a trance,

who makes a terrible slaughter

of all horror in his breast -

by his dealings you would never know

that Apollyon now was dead. ${ }^{2}$

The reference to Apollyon indicates that Smith has Bunyan's Pilgrim's Progress in mind, and he is keen to point out the contrast between the supposed solace of internal meditation and the outward action which lacks love and kindliness - the contrast between profession and practice, the inward and the outward. This is of particular interest in the context of the nascent crofters' rebellion, given the connection which certain historians have identified between the growth of radicalism in Britain and the foundational significance of Pilgrim's Progress. The English historian E. P. Thompson states (1986: 34-35):

And it is above all in Bunyan that we find the slumbering Radicalism which was preserved through the eighteenth century and which breaks out again and again in the nineteenth. Pilgrim's Progress is, with Rights of Man, one of the two foundation texts of the English working-class movement: Bunyan and Paine, with Cobbet and Owen, contributed most to the stock of ideas and attitudes which make up the raw material of the movement from 1790-1850. Many thousands of youths found in Pilgrim's Progress their first adventure story, and would have agreed with Thomas Cooper, the Chartist, that it was their 'book of books'.

As Thompson indicates, for English dissenters Apollyon was not only a symbol of repressive earthly magistrates, he was also a cunning spiritual enemy who could insinuate himself into the lives of Christians. Both strands of interpretation may lie behind Smith's sentiments in this song.

Smith was obviously familiar with Bunyan, and implies that certain - probably many Christians in Lewis were likewise familiar with him, and perhaps using him as a model, as well as being influenced by his narratives. Can this be substantiated from the surviving evidence anywhere in the Highlands? To what extent did Bunyan's paradigm of the godly life influence Highland evangelicalism at the personal and spiritual level?

To answer that question, and to round off this contribution, I would like to step back a century, to the middle years of the eighteenth century, between the 'Forty-five Rebellion and approximately 1750. In that year the first Gaelic translation of a Puritan text appeared. As we noted at the outset of this paper, it was a translation of Richard Baxter's Call to the Unconverted, and it was undertaken by the Rev. Alexander MacFarlane, who was then minister of the parish of Kilninver in Argyll. The translation is an indicator of a growing level of interest in Puritan texts in the southern Highlands. It is clear that Puritan influence had been entering the Highlands for some years previously, and that Bunyan was being read alongside Baxter, but in English, not Gaelic. The most remarkable evidence for Bunyan's influence on the early Highland missionary movement is found in the surviving work of the Gaelic hymnwriter, Dugald Buchanan (1716-68).

Buchanan, a native of Ardoch, in Strathyre, Perthshire, became a schoolmaster with the Forfeited Estates, serving in Kinlochrannoch, Perthshire, from the early 1750s until his death. Buchanan was a highly accomplished writer in both Gaelic and English, and, alongside the hymns for which he is famous, he wrote a diary of his early spiritual experiences. He went through a deep personal crisis in the 1740s, and, even after his conversion, he had great doubts about his state of grace, and agonised over his lack of assurance. His personal crisis is graphically recorded in his diary, where he notes the following in relation to his spiritual search during his teenage years (MacBean [1919]: 140):

\footnotetext{
${ }^{2}$ For Gaelic text and English translation, see Meek 1995: 90-97, 213-20.
} 
Not long after this I met with a book called, Grace Abounding to the Chief of Sinners. The title page suited me very well, for I thought that was surely I. In reading this book I found that its author had been a great sinner, and yet obtained mercy. Then I said, peradventure the Lord will be merciful to me also, since mercy is offered to the chief of sinners. This greatly encouraged me to go the Lord in prayer and confess my sins; in doing which, I found such great meltings of heart, that sometimes I would be in floods of tears, and resolved never to forsake the Lord all my days.

Buchanan does not name Bunyan, but he does not need to, as the title of the book tells us all we need to know. This was Bunyan's autobiography, written when he was undergoing twelve years of imprisonment in Bedford jail, and first published in 1666. When Buchanan wrote his own diary in the late 1740s - it remained unpublished until 1836 - he used the standard Puritan model of spiritual autobiography. The influence of Bunyan can be detected there particularly clearly, and, in the early stages of the work, the characters and experiences of Bunyan and Buchanan seem to merge. Like Bunyan, Buchanan is terrified at the prospect of the Day of Judgement; like Bunyan too, he has close shaves with death in his unregenerate days, and narrowly escapes drowning (twice). And like the majority of Puritans who have recorded their spiritual pilgrimages, his greatest struggles are after his conversion, as he strives to find marks of grace which would assure him of his salvation. The material world is almost totally erased in this great quest; we are at a loss to gain meangingful biographical details from Buchanan's diary, since he records only those events which have contributed to his spiritual development. In short, Buchanan epitomises in the Highland context what Owen Watkins (1972) has called the 'Puritan Experience'.

The model of Buchanan's life was hugely influential, particularly through his hymns. He became the archetype of godly living in the southern Highlands, and his influence spread northwards through the Perthshire glens, transmitted by print and by word of mouth, and by song, until it reached such men as Peter Grant of Grantown-on-Spey. Like Bunyan, Buchanan became a living legend, a man whose legend was greater than his life.

Even the most cursory look at the place of John Bunyan in the Gaelic spiritual context is enough to underline the Puritan - and English - dimension in what is sometimes loosely termed 'Highland religion'. 'Highland religion' was not a particularised, essentialist, self-contained Gaelic - or 'Celtic' - phenomenon. It was an extremely complex 'collection' of religious ideas. It was driven by external impulses such as those that were experienced by Dugald Buchanan, and some of those impulses originated not in Beauly or in Back, but in far-away Bedford. They intermingled with indigenous perspectives in such a way that Buchanan's diary contains more than one 'voice': there is Buchanan's own voice, but there is also the voice of Bunyan, and the voice of Scripture, to name but three. There are similar questions with regard to the Gaelic translations of John Bunyan's works. Who speaks through them? Bunyan of Bedford? Or another Bunyan, remade to fit the Highland and Gaelic context? What has been lost and gained in translation, in terms of both the words and the ideas? These are intriguing questions, worthy of much further examination.

Just occasionally, Dugald Buchanan drops his Puritan guard, and he does relate some interesting personal snippets in his diary. Rather unexpectedly, he tells us that he wore 'a Highland dress' on one occasion when he was in Edinburgh, and that someone asked him on that occasion 'what were [his] principles' (MacBean [1919]: 156-57).

It was a good question. Sometimes I wonder who Buchanan really was, and what his principles were (Meek 2009). Was he his true self as he wrote his diary, and tried to accommodate himself to the Puritan paradigm? Or was he, in fact, the first of many John Bunyans in the kilt?

Even if Buchanan were to plead guilty to identity theft, he would not, of course, be alone in his 'confessions', nor would he be doing John Bunyan a disservice. In an era when 'postcolonial studies' are increasingly fashionable and scholars are aware of the significance of key texts which were translated from English into other languages within the former British Empire, the study of the translation of Bunyan's principal works has particular importance. These works were personal in 
their application, but they were also highly 'portable' and transnational in their appeal. They became part of the bedrock of a new self-definition which accompanied the penetration of previously 'isolated' regions by an English-based majority culture. The evidence provided by Gaelic translations of Bunyan, which appear most prominently after 1800, is but a small part of the international picture of the ready acceptance of a Protestant 'authority figure' who had an uncanny knack of reinventing himself happily in many different cultures (Hofmeyer 2010).

\section{SOURCES}

DunAn-PAge, AnNe (ED.).

2010 The Cambridge Companion to Bunyan. Cambridge.

HOFMEYER, ISABEL.

2010 'Bunyan: colonial, postcolonial'. Anne Dunan-Page, The Cambridge Companion to Bunyan. Cambridge: 162-76.

MacBean, Lachlan (ED.).

[1919] Buchanan, the Sacred Bard of the Scottish Highlands; his confessions and his spiritual songs. London.

MaCGHILLINNEIN, CALUM.

1953 Turus a' Chriosduidh. Lunnainn.

MACLEAN, DONALD.

1915 Typographia Scoto-Gadelica. Edinburgh

MACLEOD, RODERICK.

1986 'The John Bunyan of the Highlands: the life and work of the Rev. Robert Finlayson (1793-1861)'. Transactions of the Gaelic Society of Inverness 54 (1984-86): 240-268.

MEEK, Donald E.

1995 (ED.) Tuath is Tighearna: Tenants and Landlords: an anthology of Gaelic poetry of social and political protest from the Clearances to the Land Agitation (18001890). Edinburgh.

1996 The Scottish Highlands: The Churches and Gaelic Culture. Geneva.

1998 'Gaelic Bible, revival and mission: the spiritual rebirth of the nineteenthcentury Highlands'. James Kirk (ed.), The Church in the Highlands. Edinburgh: 114-45.

2002a 'The pulpit and the pen: clergy, orality and print in the Scottish Gaelic world'. Adam Fox and Daniel Woolf (eds), The Spoken Word: oral culture in Britain, 1500-1850. Manchester: 84-118.

2002b "The Glory of the Lamb": the Gaelic hymns of Peter Grant'. D. W. Bebbington (ed.), The Gospel in the World: Studies in Baptist History and Thought, vol. I. Carlisle: 129-164. 


\section{JOHN BUNYAN IN THE KILT}

2009 'Evangelicalism, Ossianism and the Enlightenment: the many masks of Dugald Buchanan'. Christopher MacLachlan (ed.), Crossing the Highland Line: cross-currents in eighteenth-century Scottish writing. Glasgow: 97112.

SHARROCK, ROGER.

1968

John Bunyan. London.

SHENTON, Tim.

2001 Christmas Evans: the life and times of the one-eyed preacher of Wales. Darlington.

ThOMPSON, E. P.

1986 The Making of the English Working Class. Harmondsworth.

WATKINS, OWEN.

1972

The Puritan Experience. London.

WILLIAMS, IOAN.

2000

'Gwilym Hiraethog (William Rees, 1802-83)'. Hywel Teifi Edwards (ed.), A Guide to Welsh Literature c. 1800-1900, vol. 5. Cardiff: 48-68. 